BIODIK: Jurnal IImiah Pendidikan Biologi
ISSN 2580-0922 (online), ISSN 2460-2612 (print)
Volume 7, Nomor 01, Tahun 2021, Hal. 84-94
Available online at:
https://online-journal.unja.ac.id/biodik

Research Article OPEN ACCESS

\title{
Pengembangan Rencana Pelaksanaan Pembelajaran Model Problem Based Learning Daring untuk Meningkatkan Motivasi Belajar Siswa Materi Perubahan Lingkungan
}

\section{(Development of Online Problem Based Learning Implementation Plans to Increase Student Motivation on Environmental Change Materials)}

\author{
Roni Handika Putra*, Asrial, Jefri Marzal \\ Universitas Jambi \\ JI. Raden Mattaher No.21, Ps. Jambi, Kota Jambi, Jambi 36133, Indonesia \\ *Corresponding Authors: handikaroni94@gmail.com
}

\begin{tabular}{|c|c|}
\hline Informasi Artikel & ABSTRACT \\
\hline $\begin{array}{l}\text { Submit: } 29-12-2020 \\
\text { Diterima: } 27-02-2021 \\
\text { Dipublikasikan: } 16-03-2021\end{array}$ & $\begin{array}{l}\text { The design of RPP model PBL online in biology learning is very necessary, the } \\
\text { reason is because in biology there is a lot of material that requires the design of } \\
\text { online PBL model lesson plans to facilitate the delivery of material by teachers to } \\
\text { students. The application of the RPP model PBL online can be used by the teacher } \\
\text { as a guide in learning. The reason is because of the lack of teacher guidelines in } \\
\text { designing RPP model PBL online lesson plans. Efforts that can be made to overcome } \\
\text { this problem are by designing the optimal RPP model PBL online. The purpose of this } \\
\text { research is to produce a product, determine the development process and feasibility } \\
\text { and to determine the increase in student motivation after online learning. This } \\
\text { research is a development research. The research design follows the ADDIE } \\
\text { development model which consists of } 5 \text { stages, namely analysis, design, } \\
\text { development, implementation and evaluation. Products RPP model PBL online } \\
\text { before being tested are first validated by expert lecturers using a 3-stage validation } \\
\text { questionnaire with the final percentage acquisition of } 88.75 \% \text { with a very valid } \\
\text { category, can be used without revision. After that the product of the RPP model PBL } \\
\text { online was given to } 2 \text { biology subject teachers to see perceptions, using the teacher's } \\
\text { perception questionnaire, the results obtained were } 84.37 \% \text { with a very good } \\
\text { category, thus the RPP model PBL online was said to be feasible to be applied in } \\
\text { learning. Furthermore, online learning is carried out in large groups of class kelas } \\
\text { MIPA } 1 \text { students consisting of } 20 \text { students. After the trial was carried out, students } \\
\text { were given a motivation questionnaire and obtained results with a percentage of } \\
81.87 \% \text { in the very good category. From the test results obtained, it can be concluded } \\
\text { that the development of RPP model PBL online lesson plans can increase student } \\
\text { learning motivation. } \\
\text { Kev words: Motivation RPP online problem based learnina model }\end{array}$ \\
\hline Penerbit & ABSTRAK \\
\hline $\begin{array}{l}\text { Program Studi Pendidikan } \\
\text { Biologi, Fakultas Keguruan dan } \\
\text { Ilmu Pendidikan, Universitas } \\
\text { Jambi }\end{array}$ & $\begin{array}{l}\text { Rancangan RPP model PBL daring dalam pembelajaran biologi sangat diperlukan, } \\
\text { alasannya karena pada mata pelajaran biologi banyak sekali materi yang } \\
\text { memerlukan rancangan RPP model PBL daring untuk mempermudah dalam } \\
\text { penyampaian materi oleh guru kepada siswa. Penerapan RPP model PBL daring } \\
\text { dapat digunakan guru sebagai pedoman dalam pembelajaran. Alasannya, karena } \\
\text { minimnya pedoman guru dalam merancang RPP model PBL daring. Upaya yang } \\
\text { dapat dilakukan untuk mengatasi hal teersebut adalah dengan merancang RPP } \\
\text { model PBL daring secara maksimal. Tujuan penelitian ini adalah untuk menghasilkan } \\
\text { produk, mengetahui proses pengembangan dan kelayakan serta untuk mengetahui } \\
\text { peningkatan motivasi siswa setelah pembelajaran daring. Penelitian ini merupakan } \\
\text { penelitian pengembangan. Desain peneltian mengikuti model pengembangan ADDIE }\end{array}$ \\
\hline
\end{tabular}


yang terdiri dari 5 tahap yaitu analisis, desain, pengembangan, implementasi dan evaluasi. Produk RPP model PBL daring sebelum diujicobakan terlebih dahulu divalidasi oleh dosen ahli menggunakan angket validasi sebanayak 3 tahap dengan perolehan persentse akhir $88,75 \%$ dengan kategori sangat valid, dapat digunakan tanpa revisi. Setelah itu produk RPP model PBL daring diberikan kepada 2 guru mata pelajaran biologi untuk melihat persepsi, menggunakan angket persepsi guru, diperoleh hasil dengan persentase $84,37 \%$ dengan kategori sangat baik, dengan demikian RPP model PBL daring dikatakan layak diterapkan dalam pembelajaran. Selanjutnya pembelajaran daring dilaksanakan pada kelompok besar siswa kelas $X$ MIPA 1 yang terdiri dari 20 orang siswa. Setelah uji coba dilaksanakan siswa diberikan angket motivasi dan memperoleh hasil dengan persentase $81,87 \%$ dengan kategori sangat baik. Dari hasil uji coba yang diperoleh dapat disimpulkan bahwa pengembangan RPP model PBL daring dapat meningkatkan motivasi belajar siswa. Kata kunci: Motivasi, RPP model problem based learning daring.

\section{(c) (i) (2)}

BY NC SA

This BIODIK : Jurnal IImiah Pendidikan Biologi is licensed under a CC BY-NC-SA (Creative Commons Attribution-ShareAlike 4.0 International License)

\section{PENDAHULUAN}

Rancangan Rencana Pelaksanaan Pembelajaran (RPP) model Problem Based Learning (PBL) daring dalam pembelajaran biologi sangat diperlukan, alasannya karena pada mata pelajaran biologi banyak sekali materi yang memerlukan rancangan RPP model PBL daring untuk mempermudah dalam penyampaian materi oleh guru kepada siswa. RPP model PBL daing yang dirancang akan berpengaruh kepada semangat belajar siswa. Tentunya tidak lepas dari peran guru yang mampu merancang RPP model PBL daring secara maksimal dengan menciptakan pembelajaran yang kondusif dan bisa membangkitkan semangat siswa dalam belajar. Salah satu rancangan RPP model PBL daring yang dapat digunakan oleh guru dalam pembelajaran adalah rancangan RPP dengan mengintegrasikan teknologi. Guru diharuskan memiliki keterampilan untuk mengintegrasikan teknologi dalam merancang RPP model PBL daring, alasannya, karena sistem pendidikan sekarang selalu mengalami paradigma perubahan kebijakan atau peraturan, dari pembelajaran yang konvensional tatap muka di dalam kelas menjadi pembelajaran jarak jauh (daring) menggunakan teknologi.

Menurut Husaini, M. (2020) RPP daring diperlukan guru dalam pembelajaran jarak jauh menggunakan teknologi. Peningkatan kemampuan menyusun RPP daring penting untuk meningkatkan kemampuan profesional guru. Fanny, A. M., Satianingsih, R., Rusminati, S. H., Fanani, A., \& Prastyo, D. (2021) menambahkan bahwa akibat pandemi covid-19 telah memaksa guru untuk mampu beradaptasi dengan perubahan yang ada. Perubahan dari pembelajaran tatap muka menjadi pembelajaran secara on line (daring). Maka guru dipaksa untuk dapat menyelenggarakan pembelajaran secara daring, baik persiapan maupun pelaksanaanya. Menurut Gunawan, G. (2020) diperlukan peran pengawas sekolah dalam memberikan supervisi dalam pelaksanaan pembelajaran daring. Mengingat guru saat ini belajar dalam menggunakan aplikasi pembelajaran daring tentu masih banyak kendala dan kesalahan. Rizki, K. H. (2021) menambahkan bahwa perencanaan pembelajaran daring perlu mempertimbangkan aspekaspek dari kesulitan materi, karaktersistik siswa dan berbagai sumber belajar yang dapat digunakan untuk mendorong motivasi siswa supaya dapat memahami materi pelajaran dengan baik dan tercapai tujuan pembelajaran. 


\section{METODE PENELITIAN}

Penelitian ini merupakan bagian dari penelitian pengembangan. Tujuan utama penelitian pengembangan ini untuk menghasilkan produk tertentu dan mengetahui kelayakan produk yang dikembangkan. Model pengembangan yang digunakan dalam penelitian ini yaitu model pengembangan ADDIE. Model ADDIE menggunakan lima tahap pengembangan yakni: Analysis, Design, Development, Implementation dan Evaluation. Alasan digunakan model pengembangan ini adalah sifatnya yang deskriptif untuk menguraikan alur atau tahapan yang harus diikuti dari awal hingga akhir untuk mendapatkan suatu produk.

Pengembangan perangkat pembelajaran biologi berbasis model Problem Based Learning (PBL) untuk meningkatkan motivasi belajar siswa kelas VIII diperoleh hasil bahwa penerapan RPP yang dikembangkan dapat meningkatkan motivasi belajar siswa memperoleh penilaian dari angket motivasi 93,5\% dengan kategori sangat baik. Kemudaian didukung oleh penelitian yang dilakukan oleh Cahyono (2017) tentang pengembangan perangkat pembelajaran model Problem Based Learning berorientasi pada kemampuan berpikir kreatif dan inisiatif siswa. Penelitian ini diperoleh hasil Penelitian ini mengembangkan perangkat pembelajaran matematika yang valid, praktis, dan efektif. Hasil validasi menunjukkan perangkat yang dikembangkan valid dengan kriteria sangat baik. Kepraktisan pada uji coba lapangan mencapai kategori sangat baik dengan rata-rata keterlaksanaan 94,03\%.

Model pengembangan yang digunakan dalam penelitian ini yaitu model pengembangan ADDIE. Model ADDIE menggunakan lima tahap pengembangan yakni: Analysis, Design, Development, Implementation dan Evaluation. Alasan digunakan model pengembangan ini adalah sifatnya yang deskriptif untuk menguraikan alur atau tahapan yang harus diikuti dari awal hingga akhir untuk mendapatkan suatu produk. Adapun langkah-langkah pengembangan model ADDIE dapat dilihat pada Gambar.1

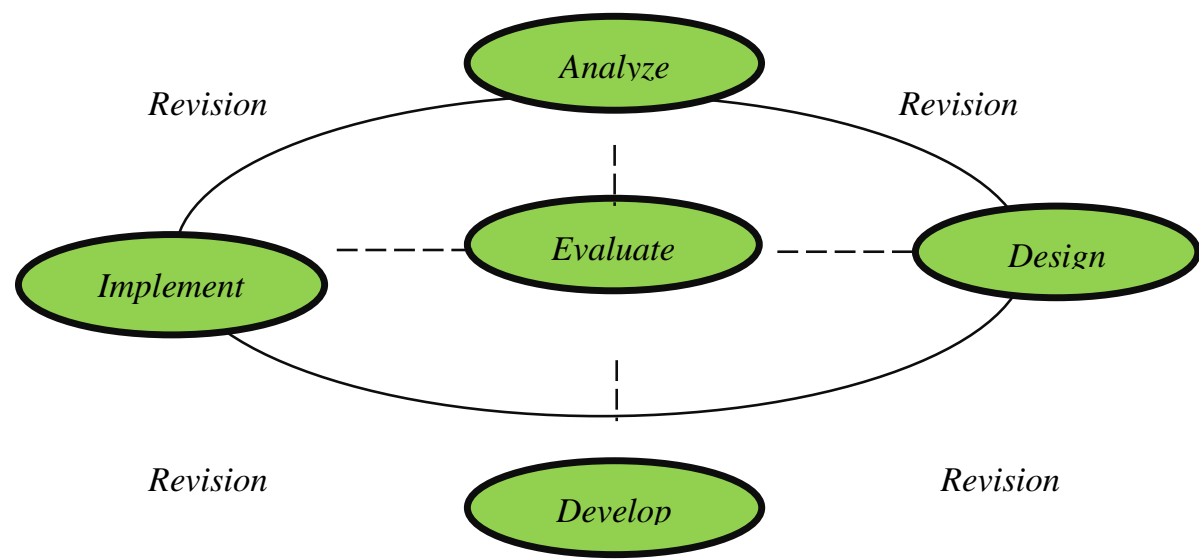

Gambar 1. Konsep Model ADDIE (Sumber: Branch, 2009:2)

Pertama tahap Analisis (Analyze) dilakukan identifikasi penyebab permasalahan yang terjadi dalam pembelajaran. Pada tahap ini juga dilakukan identifikasi apakah RPP daring dibutuhkan oleh guru dan siswa. Kedua terdapat tahap Desain (Design)Tahap desain terdiri dari penentuan tim pengembang, penentuan jadwal pembuatan RPP daring problem based learning, menentukan cakupan materi, spesifikasi produk Spesifikasi RPP daring, pembuatan storyboard dan menyiapkan sumber daya yang diperlukan. Kemudian tahap Pengembangan (Development) Pada tahap pengembangan langkah awal yang dilakukan adalah menyusun dan mengembangkan RPP daring. Pengumpulan data 
pendukung (Panduan membuat RPP model PBL daring). Selanjutnya setelah semua terkumpul, dilakukan pembuatan produk RPP daring. Selanjutnya ada tahap Implementasi (Implementation) Tahap keempat adalah implementasi RPP model PBL daring yang dilakukan pada siswa kelas X MIPA 1 di SMA Negeri 11Jambi. Pada tahap implementasi juga dilakukan untuk melihat motivasi belajar siswa. Terakhir ada tahap Evaluasi (Evaluation) Pada tahap ini kegiatan yang dilakukan adalah evaluasi secara keseluruhan apakah produk yang dikembangkan sudah berhasil atau tidak digunakan.

Instrumen pengumpulan data dalam penelitian pengembangan ini adalah berupa angket dan wawancara guru. Menurut Riduwan (2013:53) mengatakan bahwa angket adalah daftar pertanyaan yang diberikan kepada responden yang bersedia memeberikan tanggapan sesuai dengan keinginan peneliti. Angket yang digunakan dalam mengumpulkan data adalah angket analisis kebutuhan siswa, pedoman wawancara guru, analisis RPP model PBL daring yang digunakan guru, angket validasi dosen ahli, angket persepsi guru dan angket motivasi belajar siswa setelah pembelajaran daring dilakukan.

Angket yang digunakan dalam penelitian ini adalah angket skala likert. Menurut Riduwan (2013:86) skala likert digunakan untuk mengukur sikap, pendapat dan persepsi seseorang atau kelompok. Dalam penelitian ini yang dilihat adalah motivasi belajar daring peserta didik, persepsi pendidik mengenai RPP daring, validasi dosen ahli perangkat pembelajaran RPP daring model problem based learning materi perubahan lingkungan di SMA Negeri 11 Kota Jambi. Teknik analisis untuk menghitung persentase tanggapan adalah:

Tabel 1 Kategori tingkat validitas

\begin{tabular}{cccc}
\hline NO & SKALA NILAI & SKOR PERSENTASE & KATEGORI \\
\hline 1 & 4 & $80 \%-99,5 \%$ & Sangat Baik \\
2 & 3 & $60 \%-79,5 \%$ & Baik \\
3 & 2 & $40 \%-59,5 \%$ & Tidak Baik \\
4 & 1 & $12 \%-39,5 \%$ & Sangat Tidak Baik \\
\hline
\end{tabular}

Adaptasi dari Sugiyono, (2017)

\section{HASIL PENELITIAN DAN PEMBAHASAN}

Rencana Pelaksanaan Pembelajaran (RPP) model problem based learning (PBL) daring dikembangkan menggunakan model pengembangan ADDIE yang terdiri dari 5 langkah yaitu analysis, design, development, implementation dan evaluation. Adapun hasil pengembangan berdasarkan langkah-langkah di bawah ini adalah sebagai berikut:

Analisis (Analysis): Tahap analisis ini dilakukan identifikasi penyebab permasalahan yang terjadi dalam pembelajaran. Ada beberapa yang di anallisis pada tahap ini pertama analisis hasil kebutuhan siswa. Kedua analisis hasil wawancara dengan guru. Ketiga analisis RPP daring yang digunakan guru sebelumnya. Hasil analisis angket kebutuhan siswa dapat dilihat pada tabel 2.

Tabel 2. Hasil analisis angket kebutuhan siswa

\begin{tabular}{|c|c|c|c|c|c|}
\hline \multirow{2}{*}{ ASPEK } & \multirow{2}{*}{ INDIKATOR } & \multicolumn{2}{|c|}{ SKOR } & \multicolumn{2}{|c|}{ PERSEN } \\
\hline & & $Y$ & $T$ & $Y$ & $T$ \\
\hline $\begin{array}{l}\text { Pengetahuan } \\
\text { siswa tentang }\end{array}$ & $\begin{array}{l}\text { Didalam mata pelajaran biologi terdapat materi perubahan } \\
\text { lingkungan, apakah ananda paham dengan materi tersebut? }\end{array}$ & 16 & 4 & $65,4 \%$ & $34,6 \%$ \\
\hline $\begin{array}{l}\text { pembelajaran } \\
\text { biologi materi } \\
\text { perubahan } \\
\text { lingkungan }\end{array}$ & $\begin{array}{l}\text { Apakah ananda mengalami kesulitan dalam mempelajari materi } \\
\text { perubahan lingkungan? }\end{array}$ & 17 & 3 & $73,0 \%$ & $27,0 \%$ \\
\hline
\end{tabular}




\begin{tabular}{|c|c|c|c|c|c|}
\hline \multirow{2}{*}{$\begin{array}{l}\text { Pengetahuan } \\
\text { siswa terhadap } \\
\text { model } \\
\text { pembelajaran } \\
\text { problem based } \\
\text { learning }\end{array}$} & $\begin{array}{l}\text { Apakah ananda sudah mengetahui tentang model pembelajaran } \\
\text { berbasis masalah? }\end{array}$ & 18 & 2 & $84,6 \%$ & $15,4 \%$ \\
\hline & $\begin{array}{l}\text { apakah ananda pernah diberikan inovasi dalam pembelajaran } \\
\text { berbasis maslah? }\end{array}$ & 17 & 3 & $73,5 \%$ & $26,5 \%$ \\
\hline \multirow{7}{*}{$\begin{array}{l}\text { Pengetahuan } \\
\text { siswa terhadap } \\
\text { pembelajaran } \\
\text { daring } \\
\text { menggunakan } \\
\text { aplikasi }\end{array}$} & $\begin{array}{l}\text { Apakah ananda sudah mengetahui tentang pembelajaran } \\
\text { berbasis daring? }\end{array}$ & 17 & 3 & $73,6 \%$ & $26,4 \%$ \\
\hline & apakah ananda pernah diberikan pembelajaran secara daring? & 16 & 4 & $65,5 \%$ & $34,5 \%$ \\
\hline & $\begin{array}{l}\text { Menurut ananda apakah pembelajaran daring yang diterapkan } \\
\text { sudah bisa dipahami? }\end{array}$ & 18 & 2 & $84,0 \%$ & $16,0 \%$ \\
\hline & $\begin{array}{l}\text { Pembelajaran daring merupakan pembelajaran yang dilakukan } \\
\text { secara online menggunkan aplikasi sosial media seperti WAG, } \\
\text { Zoom dan YouTube. Apakah ananda mengetahui dan pernah } \\
\text { menggunakannya? }\end{array}$ & 19 & 1 & $96,1 \%$ & $3,9 \%$ \\
\hline & $\begin{array}{l}\text { Menurut ananda apakah perlu diberikan referensi tambahan } \\
\text { dalam mempelajari pokok bahasan perubahan lingkungan? }\end{array}$ & 19 & 1 & $97,0 \%$ & $3,0 \%$ \\
\hline & $\begin{array}{l}\text { Setujukah ananda jika pembelajaran daring menggunakan } \\
\text { aplikasi WAG, Zoom dan YouTube diterapkan dalam } \\
\text { mempelajari pokok bahasan perubahan lingkugan? }\end{array}$ & 18 & 2 & $85,0 \%$ & $15,0 \%$ \\
\hline & TOTAL & 175 & $87,5 \%$ & TOTAL & 175 \\
\hline
\end{tabular}

Adapun langkah-langkah menganalisis data angket kebutuhan siswa adalah sebagai berikut: Memberikan skor kepada setiap jawaban siswa, pembobotan digunakan skala guttman, dimana skala ini menginginkan tipe jawaban tegas, maka jawaban itu dapat diberi skor sebagai berikut, yaitu: 1 jika jawaban YA dan 0 jika jawaban TIDAK. Rubrik penilaian angket analisis kebutuhan siswa dapat dilihat pada tabel 3.

Tabel 3. Kategori analisis angket kebutuhan siswa

\begin{tabular}{ccccc}
\hline NO & JAWABAN & NILAI & SKOR & KETERANGAN \\
\hline 1 & Ya & 1 & $50-99,5$ & Sangat Baik \\
\hline 2 & Tidak & 0 & $10-49,5$ & Sangat Tidak Baik
\end{tabular}

\footnotetext{
Adaptasi dari Sugiyono, (2017).
}

Berdasarkan tabel 3 hasil analisis angket kebutuhan siswa terhadap pembelajaran daring model Problem Based Learning menggunakan aplikasi WAG, Zoom dan YouTube yang akan dilaksanakan pada mata pelajaran biologi materi perubahan lingkungan memperoleh skor 87,5 skala nilai berada anatara 50 - 99,5 dengan kategori sangat baik. Hasil wawancara guru mta pelajaran biologi dapat dilihat pada tabel 4 .

Tabel 4. Hasil wawancara guru biologi.

\begin{tabular}{cc}
\hline NO & HASIL WAWANCARA \\
\hline 1 & $\begin{array}{l}\text { Proses pembelajarannya biasanya hanya dilakukan dengan cara memberikan bahan pembelajaran melalui aplikasi } \\
\text { edmodo dan pertemuan pembelajaran menggunakan google classs room dan google meet. }\end{array}$ \\
2 & $\begin{array}{l}\text { lya, saya pribadi mengalami kendala, salah satu kendalanya adalah sulitnya sebagian siswa memahami materi } \\
\text { tersebut jika hanya dilakukan dengan membagikan materi kedalam aplikasi edmodo saja. }\end{array}$ \\
3 & $\begin{array}{l}\text { Sesuai dengan rencana pemebelajaran saya menggunakan model Problem Based Learning. } \\
4\end{array}$ \\
Saya sudah menerapkan model problem based learning dalam pembelajaran, namun pada kenyataan di kelas saya
\end{tabular}

\section{8


masih merasa belum maksimal dalam penerapan sintaksisnya.

5 lya, saya sudah pernah menerapkannya secara daring

6 Masih belum sepenuhnya mendapatkan hasil yang memuaskan, ada sebagian siswa memang perlu pendekatan secara khusus untuk bisa mengerti tentang materi yang disampaikan.

7 Sangat bagus bila diterapkan pembelajaran seperti itu, sebagai pembelajaran alternatif masa pandemi covid-19 ini.

8 Boleh, saya setuju, jika dengan cara seperti itu membuat para siswa bisa akan mengerti lebih mudah lagi dan meningkatkan motivasi belajar tentang materi perubahan lingkungan.

9 Yang paling utama dibutuhkan adalah jejaring sosial internet untuk mengakses bahan pembelajaran secara luas, kemudian selain itu ada android yang bisa dimanfaatkan sebagai media untuk pembelajaran daring.

10 Harapan saya semoga dapat terlaksana dengan baik.

Berdasarkan tabel 4 hasil wawancara dengan guru biologi diketahui bahwa dalam proses pembelajaran daring telah menerapkan model Problem Based Learning dan telah menggunakan aplikasi edmodo, google meet dan google class roomnamun belum maksimal dalam penerapan langkah-langkah atau sintaksis setiap tahapnya. Analisis RPP daring guru yang digunakan di SMA Negeri 11 Kota Jambi dapat dilihat pada tabel 5.

Tabel 5 Hasil analisis RPP model PBL daring guru mata pelajaran.

\begin{tabular}{|c|c|c|}
\hline NO & $\begin{array}{l}\text { HASIL ANALISIS RPP DARING } \\
\text { GURU MATA PELAJARAN }\end{array}$ & $\begin{array}{c}\text { HASIL RPP DARING } \\
\text { YANG DIKEMBANGKAN PENELITI }\end{array}$ \\
\hline 1 & Format dalam bentuk cetak sebanyak 1 lembar. & Format dalam bentuk cetak sebanyak 16 lembar. \\
\hline 2 & Tidak terdapat tahap persiapan pembelajaran. & $\begin{array}{l}\text { Terdapat tahap persiapan pembelajaran } \\
\text { a. Membuat akun aplikasi } \\
\text { b. Menggunakan aplikasi } \\
\text { c. Link video pembelajaran }\end{array}$ \\
\hline 3 & $\begin{array}{l}\text { Tujuan pembelajaran diskusi melalui aplikasi edmodo, } \\
\text { google meet dan google class room }\end{array}$ & $\begin{array}{l}\text { Tujuan pembelajaran diskusi melalui aplikasi WAG dan } \\
\text { Zoom. }\end{array}$ \\
\hline 4 & $\begin{array}{l}\text { Tidak terdapat model yang digunakan dan sintaksis } \\
\text { dalam kegiatan pembelajaran. }\end{array}$ & $\begin{array}{l}\text { Menggunakan model pembelajaran problem base } \\
\text { learning terdapat sintaksis dalam kegiatan pembelajaran. }\end{array}$ \\
\hline 5 & $\begin{array}{l}\text { Kegiatan pembelajaran melalui aplikasi edmodo, } \\
\text { google meet dan google class room }\end{array}$ & Kegiatan pembelajaran melalui aplikasi WAG dan Zoom.. \\
\hline 6 & $\begin{array}{l}\text { Tidak terdapat alokasi waktu pada kegiatan } \\
\text { pembelajaran. }\end{array}$ & Terdapat alokasi waktu pada kegiatan pembelajaran. \\
\hline 7 & $\begin{array}{l}\text { Penyampaian materi menggunakan buku paket } \\
\text { biologi diupload dalam aplikasi edmodo, google meet } \\
\text { dan google class room }\end{array}$ & $\begin{array}{l}\text { Penyampaian materi dengan cara menonton video } \\
\text { pembelajaran biologi materi perubahan lingkungan } \\
\text { berbentuk link dari aplikasi YouTubedikirimkan dalam } \\
\text { aplikasi WAG. }\end{array}$ \\
\hline 8 & Tidak terdapat ringkasan materi dari siswa. & $\begin{array}{l}\text { Siswa membuat ringkasan materi dari video pembalajaran } \\
\text { yang ditonton dan dicermatinya. }\end{array}$ \\
\hline 9 & $\begin{array}{l}\text { Penilaian pengetahuan menggunakan quiz di google } \\
\text { form. }\end{array}$ & $\begin{array}{l}\text { Penilaian pengetahuan dengan cara latihan mengerjakan } \\
\text { soal yang dikirim dalam aplikasi WAG. }\end{array}$ \\
\hline 10 & Butir soal berbentuk pilihan ganda. & Butir soal latihan dalam bentuk urain (essay). \\
\hline
\end{tabular}

Berdasarkan tabel 5 hasil analisis RPP daring guru mata pelajaran biologi pada materi perubahan lingkungan. Dibutuhkan pengembangan dan rancangan RPP daring untuk pengembangan upaya dalam memaksimalkan langkah-langkah dalam pembelajaran daring masa pandemi covid-19 ini.

Desain (Design): Pada tahap desain RPP model PBL daring menggunakan aplikasi WAG, Zoom dan YouTube terdiri dari beberapa tahap di bawah ini sebagai berikut: Jadwal meliputi: Jadwal perancangan RPP model PBL daring dimulai dari tahap analisis RPP PBL daring yang digunakan pendidik sebelumnya pada pembelajaran biologi materi perubahan lingkungan. Analisis KI-KD, IPK, sintaks dan model pembelajaran yang digunakan, aplikasi, sampai kepada tahap penilaian. 
Perancangan RPP model PBL daring menghabiskan waktu selama 8 bulan. Jadwal perencanaan dan pengembangan RPP model PBL daring dapat dilihat pada tabel 6 .

Tabel 6 Jadwal pengembangan RPP model Problem Based Learning (PBL) daring.

\begin{tabular}{|c|c|c|c|c|c|c|c|c|c|}
\hline NO & KEGIATAN & $\begin{array}{l}\text { APR } \\
2020\end{array}$ & $\begin{array}{c}\text { MEI } \\
2020\end{array}$ & $\begin{array}{l}\text { JUN } \\
2020\end{array}$ & $\begin{array}{c}\text { JUL } \\
2020\end{array}$ & $\begin{array}{l}\text { AGU } \\
2020\end{array}$ & $\begin{array}{l}\text { SEP } \\
2020\end{array}$ & $\begin{array}{l}\text { OKT } \\
2020\end{array}$ & $\begin{array}{l}\text { NOV } \\
2020\end{array}$ \\
\hline 1 & Analisis KI- KD \& IPK & & & & & & & & \\
\hline 2 & Analisis Sintak Model & & & & & & & & \\
\hline 3 & Aplikasi & & & & & & & & \\
\hline 4 & Tahap Penilaian & & & & & & & & \\
\hline 5 & Pembuatan RPP daring & & & & & & & & \\
\hline 6 & Validasi & & & & & & & & \\
\hline 7 & Uji Coba & & & & & & & & \\
\hline 8 & Implementasi & & & & & & & & \\
\hline 9 & Evaluasi & & & & & & & & \\
\hline
\end{tabular}

Tim pengembangan meliputi: Tim pengembangan RPP model Problem Based Learning (PBL) daring memerlukan tim kerja yang terdiri dari empat orang. Keempat orang ini memiliki tugas dan perannya masing-masing. Adapun keempat orang tim kerja adalah peneliti sebagai pembuat produk, tim ahli RPP model Problem Based Learning (PBL) daring yang bertindak sebagai penilai dan memberi saran pada produk serta siswa sebagai peserta dalam pelaksanaan belajar secara daring pada tahap uji coba kelompok kecil dan besar. Pengumpulan Data Pendukung meliputi: Pengumpulan data pendukung buku panduan membuat RPP model Problem Based Learning (PBL) daring yang dilakukan peneliti untuk mencari serta mengumpulkan sumber yang relevan seperti, ringkasan materi dari video pembelajaran yang ditulis tangan, jawaban soal latihan berbentuk essay ditulis tangan, aplikasi YouTube, rumah belajar kemendibud, buku, jurnal dan sumber yang relevan lainnya. Sketsa (Storyboard) meliputi: Storyboard merupakan sketsa gambar yang disusun berurutan sesuai dengan alur cerita, dengan storyboard dapat mempermudah peneliti dalam menyampaikan ide cerita dan mendiskripsikan rancangan RPP model Problem Based Learning (PBL) daring.

Pengembangan (Development): Tahapan pengembangan ini meliputi pembuatan produk RPP model Problem Based Learning (PBL) daring meliputi: Haisl angket validasi oleh dosen ahli, hasil angket persepsi guru mata pelajaran biologi terhadap RPP model PBL daring. Pertama hasil validasi dosen ahli yang meliputi: Validasi RPP model Problem Based Learning (PBL) daring oleh validator dosen ahli Bapak. Ir. Bambang Hariyadi, M.Si., Ph.D dilakukan sebanyak 3 tahap selama \pm 5 bulan. Hasil akhir angket validasi pada tahap ke 3 dapat dilihat pada tabel 7 .

Tabel 7. Hasil validasi RPP model Problem Based Learning (PBL) daring penyempurnaan tahap ketiga

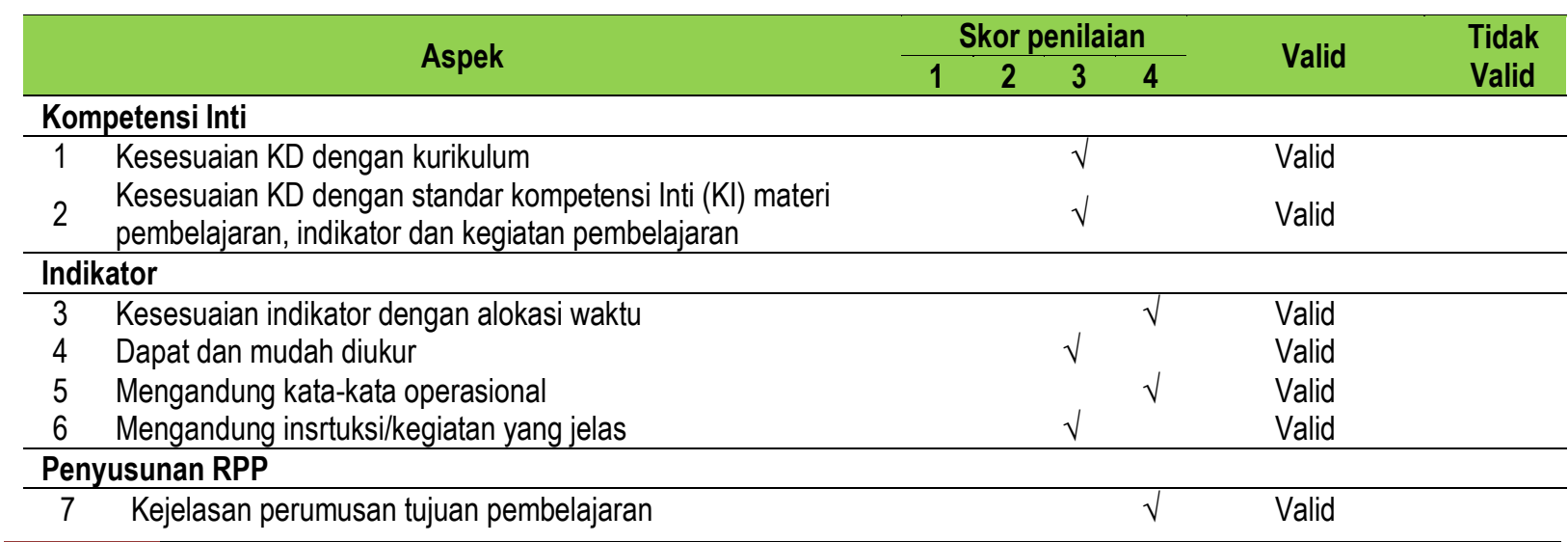




\begin{tabular}{|c|c|c|c|}
\hline 8 & \multirow{2}{*}{$\begin{array}{l}\text { Kejelasan pengorganisasian materi pembelajaran } \\
\text { Aktifitas yang dikembangkan berkontribusi pada pencapaian } \\
\text { tujuan pembelajaran yang ingin dicapai }\end{array}$} & $\sqrt{ }$ & Valid \\
\hline 9 & & $\sqrt{ }$ & Valid \\
\hline 10 & $\begin{array}{l}\text { Kesesuaian metode pembelajaran dengan scenario } \\
\text { pembelajaran }\end{array}$ & $\sqrt{ }$ & Valid \\
\hline 11 & $\begin{array}{l}\text { Aplikasi, sumber dan bahan ajar yang digunakan sesuai } \\
\text { dengan tujuan pembelajaran yang ingin dicapai }\end{array}$ & $\sqrt{ }$ & Valid \\
\hline 12 & $\begin{array}{l}\text { Langkah-langkah sesuai dengan tujuan pembelajaran yang } \\
\text { ingin dicapai }\end{array}$ & $\sqrt{ }$ & Valid \\
\hline 13 & Sintaks pembelajaran dituliskan & $\sqrt{ }$ & Valid \\
\hline 14 & $\begin{array}{l}\text { Langkah-langkah pembelajaran diuraikan secara rinci, } \\
\text { disertai dengan alokasi waktu dan media pembelajaran. }\end{array}$ & $\sqrt{ }$ & Valid \\
\hline \multicolumn{4}{|c|}{ Kegiatan Pembelajaran } \\
\hline 15 & Persiapan & $\sqrt{ }$ & Valid \\
\hline 16 & Kegiatan Pendahuluan & $\sqrt{ }$ & Valid \\
\hline 17 & Kegiatan Inti & $\sqrt{ }$ & Valid \\
\hline 18 & Penutup & $\sqrt{ }$ & Valid \\
\hline \multicolumn{4}{|c|}{ Berbasis Daring } \\
\hline 19 & Kemudahan penggunaan aplikasi pembelajaran & $\sqrt{ }$ & Valid \\
\hline 20 & $\begin{array}{l}\text { Langkah-langkah setiap penggunaan aplikasi jelas dalam } \\
\text { RPP }\end{array}$ & $\sqrt{ }$ & Valid \\
\hline
\end{tabular}

Skor Maksimal : 4 × $20=80$

Rumus:

Rentang nilai

$$
\frac{\text { Skor yang diperoleh }}{\text { Skor Maksimal }} \times 100=\text { Kategori } \quad \frac{71}{80} \times 100=88,75
$$

Tabel 8 Kategori penilaian validitas RPP model Problem Based Learning (PBL) daring tahap ketiga

\begin{tabular}{cccl}
\hline NO & SKALA NILAI & KRETERIA VALIDITAS & \multicolumn{1}{c}{ TINGKAT VALIDITAS } \\
\hline 1 & 4 & $73-89,5$ & Sangat valid, dapat digunakan tanpa revisi \\
2 & 3 & $56-72,5$ & Valid, dapat digunakan namun perlu revisi \\
3 & 2 & $39-55,5$ & Tidak valid, disarankan tidak digunakan karena perlu revisi besar \\
4 & 1 & $20-38,5$ & Sangat tidak valid, tidak boleh digunakan \\
\hline
\end{tabular}

Adaptasi dari Widoyoko, (2018:112)

Berdasarkan tabel 8 hasil penilaian validitas tahap ketiga RPP model Problem Based Learning (PBL) daring didapatkan skor 88,75 dengan demikian RPP model Problem Based Learning (PBL) daring yang dikembangkan mendapat penilaian dari dosen ahli sangat valid dengan kategori 73 - 89,5 sangat valid dan dapat digunakan tanpa revisi dan dapat diujicobakan oleh guru mata pelajaran untuk melakukan pembelajaran daring.

Kedua hasil angket persepsi guru terhadap RPP model PBL daring yang dikembangkan dapat dilihat pada tabel 9 .

Tabel 9 Kategori penilaian validitas RPP model Problem Based Learning (PBL) daring oleh guru

\begin{tabular}{cccc}
\hline NO & SKALA NILAI & INTERVAL SKOR & KATEGORI MOTIVASI \\
\hline 1 & 5 & $81,6 \%-100 \%$ & Sangat Baik \\
2 & 4 & $61,2 \%-81,5 \%$ & Baik \\
3 & 3 & $40,8 \%-61,1 \%$ & TidakBaik \\
4 & 2 & $20,4 \%-40,7 \%$ & Sangat TidakBaik \\
\hline \multicolumn{2}{l}{ Adaptasi dari Farhan, (2014). } & &
\end{tabular}


Berdasarkan tabel 9 hasil penilaian persepsi RPP model Problem Based Learning (PBL) daring oleh 2 guru mata pelajaran biologi didapatkan skor 135 dengan demikian RPP model Problem Based Learning (PBL) daring yang dikembangkan mendapat penilaian dari 2 guru mata pelajaran dengan persentase $84,37 \%$ dengan kategori $81,6 \%$ - 100\% sangat baik , dapat digunakan oleh guru mata pelajaran untuk melakukan pembelajaran daring terhadap siswa.

Implementasi (Implementation): Tahap implementasi merupakan tahapan nyata yang dilakukan setelah proses pengembangan selesai. Menurut Sumadi dkk., (2017:3) kegiatan implementasi pada dasarnya merupakan tahapan dimana menyiapkan lingkungan belajar dan mengikutsertakan siswa. Pada tahap ini dilakukan penerapan RPP model Problem Based Learning (PBL) daring yang telah dikembangkan sebelumnya dalam pembelajaran. Pada tahap implementasi juga dilakukan pengukuran motivasi belajar siswa. Peneliti menggunakan satu kelas yaitu kelas X MIPA 1 yang berjumlah 20 orang siswa diterapkannya pembelajaran secara daring menggunakan aplikasi WAG, Zoom dan Youtube serta aplikasi Google Form absensi kehadiran siswa. Hasil Motivasi Siswa Setelah pembelajaran daring dilakukan sebanyak dua kali pertemuan dengan materi perubahan lingkungan, limbah dan daur ulang dapat dilihat pada tabel di bawah 10.

Tabel 10 Hasil motivasi siswa terhadap pembelajaran daring

\begin{tabular}{|c|l|c|}
\hline NO & \multicolumn{1}{|c|}{ INDIKATOR } & $\begin{array}{c}\text { JUMLAH } \\
\text { SKOR }\end{array}$ \\
\hline 1 & Saya menyimak dan memperhatikan ketika guru menjelaskan materi pembelajaran biologi secara daring & 66 \\
\hline 2 & $\begin{array}{l}\text { Saya akan merasa bosan mengikuti pembelajaran biologi secara daring jika penyampaian materi dalam } \\
\text { bentuk video pembelajaran }\end{array}$ & 71 \\
\hline 3 & $\begin{array}{l}\text { Saya merasa senang mengikuti pembelajaran biologi secara daring jika penyampaian materi dalam } \\
\text { bentuk video pembelajaran }\end{array}$ & 60 \\
\hline 4 & Saya merasa terdorong untuk mempelajari biologi secara daring & 65 \\
\hline 5 & Saya berusaha untuk tidak terlambat ketika mengikuti pembelajaran biologi secara daring & 61 \\
\hline 6 & Saya perlu belajar biologi secara daring dengan mengunakan sumber referensi tambahan lain & 66 \\
\hline 7 & Pembelajaran biologi secara daring membuat saya aktif dan berpastisipasi dalam pembelajaran & 66 \\
\hline 8 & Saya mendapat tambahan pengetahuan yang lebih dengan belajar biologi secara daring & 67 \\
\hline 9 & Saya merasa lebih cepat memahami materi biologi setelah guru memberikan penjelasan secara daring & 66 \\
\hline 10 & Saya mampu membuat kesimpulan pada pembelajaran setelah belajar sacara daring & 69 \\
\hline 11 & Saya berharap semua materi mata pelajaran biologi menggunakan belajar secara daring & 65 \\
\hline 12 & Saya sangat suka dengan pembelajaran biologi secara daring, karena saya ingin menjadi juara kelas & 64 \\
\hline Jumlah Skor & $\mathbf{7 8 6}$ \\
\hline Rata-rata & $\mathbf{3 9 , 3}$ \\
\hline Skor Maksimal & $\mathbf{9 6 0}$ \\
\hline Presentasi & $\mathbf{8 1 , 8 7 \%}$ \\
\hline Kategori & Sangat Baik \\
\hline Adaptasi dari Suwartono, (2014:54) & \\
\hline
\end{tabular}

Hasil analisis motivasi siswa terhadap pembelajaran daring, pengambilan data motivasi siswa terhadap pembelajaran daring dilakukan berbantuan angket. Angket yang menggunakan skala persentase 4 angka jawaban. Angket yang berisi 12 pertanyaan selanjutnya dianalisis sebagai berikut:

Kategori Penilaian 4

Responden 20

Skor terendah : $1 \times 12=12$

Skor tertinggi : $4 \times 12=48$ 
Persentase $=\frac{\text { Skor yang diperoleh }}{\text { Skor Tertinggi }} \times 100$
Persentase $=\frac{48}{48} \times 100 \%=100$

Tabel 11 Kategori penilaian tingkat motivasi siswa

\begin{tabular}{cccc}
\hline NO & SKALA NILAI & INTERVAL SKOR & KATEGORI MOTIVASI \\
\hline 1 & 5 & $81,6 \%-100 \%$ & Sangat Baik \\
2 & 4 & $61,2 \%-81,5 \%$ & Baik \\
3 & 3 & $40,8 \%-61,1 \%$ & Cukup Baik \\
4 & 2 & $20,4 \%-40,7 \%$ & Kurang Baik \\
5 & 1 & $0,00 \%-20,3 \%$ & Tidak Baik \\
\hline
\end{tabular}

Adaptasi dari Farhan, (2014).

Berdasarkan tabel 11 hasil dari motivasi siswa terhadap pembelajaran daring didapatkan skor 786 dengan persentase $81,87 \%$ dengan demikian dapat dikatakan pembelajaran daring model Problem Based Learning (PBL) menggunakan aplikasi WAG, Zoom dan YouTube dapat meningkatkan motivasi belajar siswa secara daring dengan kategori $81,6 \%-100 \%$ sangat baik. Alasan kenapa model PBL dapat meningkatkan motivasi belajar, karena model PBL memiliki sintaks atau langkah-langkah pembelajaran yang terdiri dari 5 tahap yaitu: Orientasi, mengelompokan, mengarahkan pemecahan masalah, mempresentasi hasil karya serta mengevaluasi. Selain itu juga terdapat kelebihan model PBL menurut Palennari (2016) menyatakan bahwa: Siswa memperoleh pengalaman praktis baik di laboratorium maupun di lapangan, kegiatan belajar lebih menarik sebab tidak terikat di dalam kelas sehingga tidak membosankan, bahan pelajaran lebih dihayati dan dipahami oleh para siswa sebab teori disertai praktek, siswa dapat belajar dari berbagai sumber, interaksi sosial antar siswalebih banyak dikembangkan, siswa belajar melakukan analisis secara simultan baik dalam memperoleh data maupun dalam menguji jawaban sementara berdasarkan data yang diperoleh, membiasakan siswa berpikir logis dan secara sistematis dalam pemecahan masalah serta cocok diintegrasikan dengan teknologi.

\section{KESIMPULAN}

Berdasarkan analsis data dan pembahasan, maka dapat disimpulkan sebagai berikut: Pengembangan RPP model Problem Based Learning (PBL) daring pada materi perubahan lingkungan menggunakan model pengembangan ADDIE yang terdiri dari 5 tahap yakni: Analysis, Design, Development, Implementation dan Evaluation menghasilkan produk berupa RPP model Problem Based Learning (PBL) daring sebagai motivasi belajar siswa menggunakan aplikasi WAG, Zoom dan YouTube alternatif pembelajaran daring masa pandemi covid-19 dan Kelayakan RPP model Problem Based Learning (PBL) daring sebagai motivasi belajar siswa menggunakan aplikasi WAG, Zoom dan YouTube alternatif pembelajaran daring masa pandemi covid-19 berdasarkan hasil validasi dari dosen ahli diperoleh kategori sangat valid dan memperoleh hasil dari persepsi 2 orang guru mata pelajaran biologi diperoleh kategori sangat baik serta Motivasi siswa setelah belajar daring diperoleh hasil dari respon siswa terhadap pembelajaran daring yang telah diterapkan kategori sangat baik. 


\section{DAFTAR PUSTAKA}

Branch, R. M. (2009). Instructional Design-The ADDIE Approach. New York: Springer.

Cahyono, A.E.Y. (2017). Pengembangan Perangkat Pembelajaran Problem-Based Learning Berorientasi pada Kemampuan Berpikir Kreatif dan Inisiatif Siswa. Journal Pythagoras UNY, 12(1), 1-11.

Fanny, A. M., Satianingsih, R., Rusminati, S. H., Fanani, A., \& Prastyo, D. (2021). Peningkatan Kompetensi Guru Sekolah Dasar Dalam Pengembangan Rencana Pelaksanaan Pembelajaran (RPP) Daring di SDN Margorejo I Kota Surabaya Provinsi Jawa Timur. Manggali, 1(1), 66-77.

Farhan, M. (2014). Keefektifan PBL Dan IBL Prestasi Belajar ditinjau dari, Kemampuan Representasi Matematis dan Motivasi Belajar Siswa. Jurnal Riset Pendidikan Matematika, 1(2), 231.

Gunawan, G. (2020). PENINGKATAN KEMAMPUAN GURU DALAM PENGEMBANGAN SILABUS DAN RPP MODA DARING MASA PANDEMI COVID 19 MELALUI POLA PEMBINAAN PROFESIONAL DI SEKOLAH BINAAN TAHUN PELAJARAN 2020/2021:(Increasing Teachers' Competence in Designing Syllabus and Lesson Plan During Covid-19 Pandemic). Uniqbu Journal of Social Sciences, 1(3), 47-60.

Husaini, M. (2020). Peningkatan Kemampuan Guru Dalam Pengembangan Silabus dan RPP Daring Melalui Pola Pembinaan Profesional Dengan Pendekatan Kooperatif Di SD Negeri 1 Kumai Hulu Semester 2 Tahun Pelajaran 2019/2020. Anterior Jurnal, 20(1), 10-22.

Palennari, M .(2016). Problem Based Learning (PBL) Memberdayakan Keterampilan Berpikir Kritis Pebelajar Pada Pembelajaran Biologi. Prosiding Seminar Nasional Biologi dan Pembelajarannya, 22(1), 200-210.

Riduwan. (2013). Variabel-Variabel Penelitian Edisi 1. Bandung: Alfabeta.

Rizki, K. H. (2021). ANALISIS SWOT RENCANA PEMBELAJARAN LURING DAN DARING PADA PEMBELAJARAN TEMATIK KELAS 3 DI SEKOLAH DASAR NEGERI TLOGOMAS 2 (Doctoral dissertation, Universitas Muhammadiyah Malang).

Sumadi., Anggereini, A., dan Yelienti, U. (2017). Pengembangan Ensiklopedia Digital Hewan Vertebrata Berbasis Android Studio 2.2 untuk Kelas X SMA. Jurnal Pendidikan Matematika dan IImu Pengetahuan Alam Universitas Jember (Edu-Sains), 6(2), 1-10.

Sugiyono. (2017). Metode Penelitian Kuantitatif, Kualitatif dan R\&D. Bandung: Anggota Ikatan Penerbit Indonesia (IKAPI).

Suwartono. (2014). Dasar Metodologi Penelitian. Yogyakarta: Andi Offset.

Widoyoko, E.P. (2018). Teknik Penyusunan Instrumen Penelitian Edisi 1. Yogyakarta: Pustaka Pelajar. Yustianingsih, R., Syarifuddin, H., dan Yerizon. (2017). Pengembangan Perangkat Pembelajaran Matematika Berbasis Problem Based Learning (PBL) untuk Meningkatkan Kemampuan Pemecahan Masalah Peserta Didik Kelas VIII. Jurnal Nasional Pendidikan Matematika, 1(2), 258-274. 